\title{
REPRESENTAÇÕES DA INFÂNCIA EM NARRATIVAS DE MIA COUTO: A CRIANÇA ENTRE A FICÇÃO E A HISTÓRIA ${ }^{1}$
}

Eloísa Porto Corrêa Allevato Braem Lina Paula Jasbick Tonack Beckmann

Resumo: O presente artigo analisa algumas representações da infância em narrativas literárias de Mia Couto, em diálogo com a História. Nessa tarefa, partimos de definições da infância elaboradas por estudiosos do assunto, como Ariès (1981), Foucault (1995), Heloiza Castro (2019), Betina Hillesheim e Neuza Guareschi (2007). Consideramos também tratados internacionais, ratificados por Moçambique, e estudos sobre a infância moçambicana, como os de Celestino e Pastore (2018), Pastore e Barros (2016). Além disso, tecemos alguns diálogos com a fortuna crítica à obra coutiana, que conta com nomes como os de Francisco Noa (2019), Moema Marques (2012) e Petar Petrov (2014), entre outros. Com isso, esperamos contribuir para uma mais ampla compreensão da situação das crianças representadas na narrativa literária do escritor moçambicano Mia Couto.

Palavras-chave: Infância. Criança. Literatura Moçambicana. Mia Couto.

Abstract: This article analyzes some childhood representations in Mia Couto's narratives, in dialogue with History. In this task, we start with definitions of childhood elaborated by Ariès (1981), Foucault (1995), Heloiza Castro (2019), Betina Hillesheim and Neuza Guareschi (2007). We also consider international treaties, ratified by Mozambique, and studies on Mozambican childhood by Celestino and Pastore (2018), Pastore and Barros (2016). In addition, we have some dialogues with the critical works by Francisco Noa (2019), Moema Marques (2012) and Petar Petrov (2014). Thus, we hope to contribute to a better understanding of the situation of children represented in the narratives written by Mia Couto.

Keywords: Childhood. Child. Mozambican Literature. Mia Couto.

1 Título em língua estrangeira: “Childhood representations in Mia Couto's narratives: the child between fiction and history". 
A infância não é um tempo, não é uma idade, uma coleção de memórias. A infância é quando ainda não é demasiado tarde. É quando estamos disponíveis para nos surpreendermos, para nos deixarmos encantar. Quase tudo se adquire nesse tempo em que aprendemos o próprio sentimento do Tempo. (COUTO, 2011, p. 104)

Desde 1990, oficialmente, Moçambique adota o conceito de infância e as orientações difundidas pela Convenção Internacional sobre os Direitos da Criança, emitida pela ONU em 1989 e ratificada por quase todos os países do mundo, segundo a qual a infância se prolonga até os 18 anos, logo no art. 1ㅇ da Parte I: "Para efeito da presente Convenção, considera-se como criança todo ser humano com menos de 18 anos de idade, salvo quando, em conformidade com a lei aplicável à criança, a maioridade seja alcançada antes" (UNICEF, 2019, s.p.). Nesse documento, fica proclamado que todos, durante a infância, têm direito a cuidados e assistência especiais da família e do Estado, em um ambiente adequado e digno, sendo vedada a venda de crianças, a prostituição e a pornografia infantil, o envolvimento em conflitos armados e guerras antes dos 18 anos ou quaisquer outras formas de violência contra crianças. Além disso, a convenção endossa a necessidade de se proporcionar aos jovens a proteção especial enunciada na Declaração de Genebra dos Direitos da Criança, de 1924, e regra ainda procedimentos relacionados a meios de comunicação envolvendo jovens, como também 
reconhece às crianças todos os direitos e liberdades enunciados na Declaração Universal dos Direitos Humanos e nos pactos internacionais de direitos humanos, sem distinção de raça, cor, sexo, idioma, crença, opinião política, origem nacional ou social, posição econômica, nascimento ou qualquer outra condição ou natureza (UNICEF, 2019, s.p.).

Entretanto, sabemos que as práticas cotidianas nas sociedades nem sempre refletem os conceitos, abstrações e ideais legais. Além disso, também sabemos que as concepções do que seja infância, do que seja cuidado (e até do que seja violência) ou de como deva ser o processo de educação adequado e o desenvolvimento saudável precisam ser contextualizadas, pois variam muito de uma cultura para a outra e de uma época para a outra, ainda que se busque atualmente uma uniformização dessas definições, em âmbito global, até em favor de uma mais ampla (e necessária) proteção a crianças, que vêm sendo sistematicamente vítimas das mais variadas formas de abusos, maus-tratos e negligências ao longo da história dos países ou dos povos, mesmo que cada sociedade desenvolva suas próprias formas de cuidado, de violência, de educação e de definição de infância.

Essas contemporâneas concepções e tratados sobre a infância se baseiam em teorias científicas desenvolvidas ao 
longo dos séculos. Para a Psicologia, por exemplo, a infância é uma etapa ou um conjunto de etapas do desenvolvimento humano, caracterizada/s pela aquisição da linguagem e do amadurecimento em variados aspectos e habilidades dos indivíduos. A divisão e as nomenclaturas para cada uma dessas etapas vai variar muito de um estudioso para o outro e de uma corrente teórica para a outra. Para Piaget, por exemplo, o desenvolvimento infantil se dá em 4 fases subsequentes, nomeadas segundo as habilidades afetadas: sensório motora (até cerca de 2 anos, quando há descobertas e experimentos envolvendo o corpo, as sensações e as ações), pré-operatória (até cerca de 7 anos, quando a criança é individualista, coloca-se no centro de todas as situações e entra na "fase dos porquês", do faz-de-conta...), operacional concreta (até cerca de 12 anos, quando se começa a "resolver problemas concretos a partir da lógica, da abstração e do pensamento filosófico" em desenvolvimento, internalizandose regras sociais e conceitos) e operacional formal (quando se desenvolvem "capacidades de reflexão e abstração, formulam-se opiniões e conceitos sobre sociedade e sobre as relações como indivíduo, questionam-se estruturas e definem-se posicionamentos") como sistematiza e sintetiza Heloiza Castro (2019, s.p.). Nessa perspectiva, de modo muito sintético, Piaget defende que a emancipação do sujeito está 
associada à aquisição de habilidades lógico-dedutivas, desde a mais tenra infância, as quais lhe assegurariam a primazia da razão intelectual, moral e social. Estas capacidades prestigiariam valores como progresso, estabilidade, objetividade, neutralidade e ordem, imprescindíveis "à superação da natureza primitiva, à disciplina da emoção e ao controle da natureza pela ciência e pela técnica, tão apreciadas pelo homem moderno" autorregulado, como lembram as doutoras Betina Hillesheim e Neuza Guareschi (2007, s.p.).

No entanto, para Ariès (1981), a infância é uma descoberta ou uma invenção da modernidade com, ao menos, dois aspectos, na ótica adulta: 1- da infância como "ingenuidade, gentileza e graça, que se torna uma fonte de distração e de relaxamento para o adulto" (ARIÈS, 1981, p. 100); 2da infância que carece de proteção (moral, psicológica...) em relação aos adultos. Daí surge a escola, como uma das entidades que separa a criança dos adultos e a "prepara/ amadurece" para adentrar a vida adulta e para melhor conviver com os adultos, a partir de estudos sobre os comportamentos das crianças e de metodologias adequadas ao seu desenvolvimento e educação (ARIÈS, 1981, p. 104). Claro está que todas essas perspectivas são ocidentais e nem 
sempre se aplicavam a sociedades africanas, sobretudo até os processos de colonização e até, bem mais recentemente, de globalização, que difundem tais concepções e práticas cada vez mais.

Para Foucault (1995), por outro lado, “o corpo (da criança) só se torna força útil se é ao mesmo tempo corpo produtivo e corpo submisso" (FOUCAULT, 1995, p. 26), de modo que a infância só se tornaria alvo de interesse, de estudo e de controle através da educação (cada vez mais de massa) pelas sociedades, quando se busca o exercício do poder sobre a produtividade dela, ou melhor, do adulto que ela se torna.

A partir dessa multiplicidade de perspectivas, tornase imprescindível uma problematização das concepções ocidentais da infância, sobretudo se pensarmos na infância vivenciada por sujeitos e povos em culturas não ocidentais, como é o caso da moçambicana, abordada nas narrativas de Mia Couto - mesmo que a cada dia mais ocidentalizadas, como denunciam as obras coutianas e como fica demonstrado pela adesão do país a tratados e convenções da ONU, a religiões cristãs, ao consumo de bens produzidos em países ocidentais ricos etc. Pois, como lembram Betina Hillesheim e Neuza Guareschi:

A Modernidade teve como tarefa fundamental a problematização da infância, 
visto a necessidade de regulação da população no que se refere às medidas de ordem, higiene, saúde e urbanização. Dessa maneira, estabeleceram-se novas práticas de biopoder associadas aos emergentes mecanismos de governamentalidade, sendo que a vontade de saber-poder sobre as crianças se concentrou na constituição de ciências e instituições que dessem conta das mesmas. [...] Discute-se a infância como uma ideia complexa e historicamente formada mediante diferentes estratégias de poder, no seio do dispositivo da infantilidade. (2007, s.p.)

Por outro lado, na obra de Mia Couto, muitas vezes a infância funciona como representação metafórica da própria modernidade na cultura moçambicana, em constante diálogo com as influências ocidentais (escrita, língua portuguesa, cristianismo, TV...), ainda que herdeira também das ancestrais tradições moçambicanas (religiões antigas, oralidade, costumes e línguas locais etc.). Nessa dupla perspectiva crítica sobre a infância, Mia Couto aborda, em muitas narrativas, tanto a vulnerabilidade social das crianças, as privações e violações aos direitos dos menores moçambicanos, as relações de poder e o uso da força entre vários grupos sociopolíticos, que podem afetar muito a criança moçambicana; quanto também aborda o impacto da ocidentalização na cultura e no 
cotidiano moçambicano, em contraponto às tradições e raízes culturais dos povos originários.

Nesse sentido, alguns contos representam infâncias felizes ou momentos felizes na infância, quase sempre relacionados à forte relação com a terra, a cultura tradicional, os espíritos ancestrais e a natureza (animista), como a do personagem central de "O rio das quatro luzes", presente no livro $O$ fio das missangas (COUTO, 2004, p. 111-116) e na coletânea A menina sem palavras (2013a, p. 127-132), repletas de narrativas que abordam a infância. O personagem central, que ainda pequeno deseja envelhecer rápido e morrer logo, sente-se tocado pela comoção gerada pela passagem de um cortejo fúnebre e experimenta um incomum sentimento de inveja, desejando estar também num caixão como aquele. Apesar do aborrecimento dos pais com aquele estranho desejo, o menino se questionava em pensamentos: de que "valia ser criança se lhe faltava a infância?" (COUTO, 2013a, p. 130). O conto evidencia a falta de percepção dos pais em relação à necessidade do filho de viver mais intensamente a infância, imaginar, brincar... Porém, após uma visita ao avô, a vida começa a mudar, pois, ao contar-lhe sobre seu desejo de ter uma vida breve, o idoso passa a proporcionar ao menino o que ele tanto desejava e eles fazem um trato 
fantasioso: o avô negociaria com Deus um modo de o neto morrer em seu lugar, quando a hora do idoso chegasse - trato que nunca foi cumprido - no entanto, enquanto a morte não viesse, a criança teria que se aventurar "nos amplos territórios da infância" (COUTO, 2013a, p. 131) com o avô, que the mostraria as brincadeiras de seus tempos de menino. Assim, foram se afastando os pensamentos de morte e, ao final, o avô explica aos pais do garoto que era preciso têlo ensinado a ser criança, pois "criancice é como amor, não se desempenha sozinha" (COUTO, 2013a, p. 131). Esse é um conto que trabalha o valor e a configuração da infância na cultura moçambicana, extremamente relacionada à tradição, aos antepassados, à imaginação, que traduziriam o que é (ou deveria ser) um desenvolvimento saudável aos pequenos em Moçambique, ao menos na concepção coutiana. Além disso, nessa relação forte entre a criança e o avô, entre a infância e a velhice, tão recorrente em obras de Mia Couto, observamos o diálogo e, por vezes, a tensão entre o moderno e o antigo, entre a tradição e a novidade/contemporaneidade, sendo aquela mais valorizada, enquanto esta costuma ser mal vista, como exógena e aculturadora.

É o que se vê também em narrativas curtas como "A avó, a cidade e o semáforo", de O fio das missangas (COUTO, 
2004, p. 125-129) e "Sangue de avó, manchando a alcatifa", da obra Cronicando (COUTO, 1993, p. 25-26), em que o consumismo, o luxo e a fetichização de objetos como a TV são vistos pela avó como símbolos da aculturação dos mais jovens, cada vez mais distantes das tradições e das culturas originais moçambicanas. A guerra civil (conflitos internos) que leva a avó Carolina (COUTO, 1993, p. 25-26) a ir morar na cidade de Maputo com a filha e os netos - parece duplicar-se no conflito entre a tradição e a modernidade, em prejuízo da primeira, o que entristece e revolta crescentemente a idosa na capital, levando-a a se sentir relegada, esquecida. 0 conflito/confronto entre as gerações culmina na destruição da TV pela idosa, que passa a ser tida como louca pelos mais jovens, o que pode representar uma negação da tradição pelas gerações mais recentes e mais urbanas, aculturadas. Mas, a mancha de sangue na sala, que resta do conflito, depois de a avó voltar para o interior, prova que "a tradição se faz viva na sociedade moderna moçambicana", mesmo que renegada, como lembra Moama Marques (2012, p. 3).

Em "A avó, a cidade e o semáforo", de $O$ fio das missangas (COUTO, 2004, p. 125-129), a revolta da avó Carolina dá lugar ao alheamento e indigência voluntária da avó Ndzima. Ainda que esta avó opte por ficar na cidade junto ao moderno 
semáforo e não voltar para a aldeia, faz isso por "aquelas luzinhas, amarelas, vermelhas", quando fecha os olhos, lembrarem-lhe "a fogueira crepitando no velho quintal" (COUTO, 2004, p. 129). Logo, é a tradição que essa avó representa, busca e saúda também, não é a modernidade, ao cabo. Ela representa e lamenta a perda dessa tradição, da ancestralidade, dos costumes moçambicanos originais, em declínio e em desvalorização na sociedade moçambicana de sua época, não apenas nas cidades, mas também nos interiores: "Lá, na aldeia, ainda estou mais sozinha" (COUTO, 2004, p. 128).

Em obras como essas, podemos perceber que a infância feliz e plena é menos comum na obra de Mia Couto. Bem mais frequentes são os reflexos da violência e de mazelas, dos processos de aculturação, das guerras e da falta do mínimo existencial afetando personagens infantis, entristecendoas, preocupando-as, adoecendo-as, matando-as, em um país assolado por anos de conflitos armados, gerando orfandade, doenças, miséria, a dura submissão de jovens pobres ao trabalho infantil que, junto de outros fatores, veda o acesso à educação formal escolar adequada e prejudica o desenvolvimento pleno na infância. É o que ocorre em $O$ menino no sapatinho (COUTO, 2013c, s.p.), cujo personagem- 
título nasce sem berço, sem o mínimo existencial necessário, sem nem tamanho/peso de um recém-nascido, desnutrido, fraco, doente, muito menor do que qualquer bebê, enfraquecido pela miséria, pelo desamparo, pela carência, pela negligência do Estado e do pai (também carente, doente, miserável...), apesar de todos os esforços da mãe. É o que ocorre também em $O$ beijo da palavrinha (COUTO, 2008, p. 1-29), em que Poeirinha - nome que já remete à humildade, pequenez, juventude, pobreza, esquecimento... - também sofre com a falta de assistência básica, de alimento e do mínimo necessário, que acabam adoecendo e dificultando o tratamento da menina, cada vez mais debilitada.

Semelhante é o que ocorre ao menino Muidinga, que sofre de amnésia e deseja reencontrar seus pais, em Terra Sonâmbula (COUTO, 2007), com a ajuda do ancião Tuahir, fugindo da guerra civil em Moçambique. Acontece também com o filho de um pescador alcoólatra e sonâmbulo, o menino Kindzu, encontrado morto em um ônibus incendiado, logo no início da mesma Terra Sonâmbula. É Kindzu - órfão de pai e abandonado pela mãe - quem escreve suas memórias em diários, encontrados por Muidinga e Tuahir junto do cadáver do jovem, relatando dificuldades financeiras, violências, medos e peripécias que duplicam em alguns 
casos ou se somam em outros às peripécias e dificuldades experimentadas pelo jovem Muidinga e pelo idoso Tuahir, também fugindo da guerra moçambicana. São mais alguns exemplos de como a tradição é representada (em obras de Mia Couto) pelo idoso, nesse caso Tuahir (sábio, re-contador de histórias antigas orais e propagador da cultura ancestral moçambicana) em diálogo com a modernidade, simbolizada pelos jovens Muidinga e Kindzu, representantes da escrita, da cultura moçambicana atual, das novas gerações, que convivem e dialogam com as tradições e a cultura original, mas são sobremaneira influenciados pela globalizada cultura de massa ocidental, exportada pelos países ricos e consumida em Moçambique como em tantos outros países do mundo.

Nas narrativas de Mia Couto, encontram-se gerações e gerações de sujeitos devastados, que se deslocam em territórios também devastados e minados, metafórica e literalmente, já que as minas enterradas em várias partes prejudicam a população de diferentes modos, privando as crianças de viver suas infâncias, principalmente as mais pobres, como se vê em Terra Sonâmbula (COUTO, 2007) e em tantas outras obras. Esses contextos de devastação, miséria, incerteza, angústia, violência, medo, guerras, minas, fome, doenças e adversidades comprometem o desenvolvimento 
das crianças/cidadãos e do país, com famílias chorando seus entes queridos, gerações e gerações de trabalhadores traumatizados, desempregados, alcoólatras, órfãos, crianças desamparadas, como em $O$ menino no sapatinho (COUTO, 2013c, s.p.), em Terra Sonâmbula (COUTO, 2007), entre tantos outros.

Em comum, quase sempre a ausência do Estado, que não presta assistência adequada, não garante segurança e saúde públicas, não ampara nem gestantes e crianças, idosos e doentes nas obras do autor moçambicano. É o que ocorre, por exemplo, também com a personagem Filomena, do conto "A menina de futuro torcido", na coletânea $A$ menina sem palavras (COUTO, 2013a), cujo pai ouve que um rapaz, com talento para contorcionismo, fora levado por um empresário e estava fazendo fama e fortuna por aí. Como eram tempos difíceis financeiramente e, muito mais para um pai de doze filhos, o pai decide que Filomena, a filha mais velha, haveria de se tornar contorcionista e assim seria uma salvação para o futuro de toda a família. No anseio de ter uma vida melhor para si e seus filhos, passa a treiná-la à exaustão sem perceber que a saúde da menina se deteriorava. Esse é um dos reflexos da pobreza em Moçambique na obra de Mia Couto: a inversão de papéis, por exemplo, quando aos filhos 
é passada a responsabilidade de amparar ou cuidar dos pais e dos irmãos, quando os mais velhos delegam aos mais jovens a responsabilidade pelo sustento familiar, mesmo que isso possa trazer possíveis prejuízos ao desenvolvimento da criança, como ocorre em/com "A menina de futuro torcido" (COUTO, 2013a).

A exploração do trabalho infantil - tão criticada e combatida por órgãos moçambicanos de proteção à infância, mas que ainda persiste no país - fica evidenciada no infeliz desfecho de "A menina de futuro torcido" (COUTO, 2013a) quando, ao ouvir do empresário que o contorcionismo estava ultrapassado e o novo sucesso seriam pessoas com dentes de aço, o patriarca cogita a possibilidade de treinar a primogênita para desenvolver essa nova habilidade, desconsiderando o lamentável estado de saúde da filha.

Um outro exemplo do reflexo negativo sobre a infância das mazelas sofridas pelo povo moçambicano encontra-se no menino Bento Mussaleve, de "As baleias de Quissico", também disponível na coletânea $A$ menina sem palavras (COUTO, 2013a). Disposto a mudar de vida, Bento vai à região de Quissico - terra assolada pelo conflito armado por ter ouvido falar na existência de baleias que chegavam à praia e as quais davam mercadorias a quem lhes pedisse. 
Mesmo alertado pelos seus amigos de que precisava voltar para o mundo real - pois outros personagens já estavam pensando que o menino havia se juntado a reacionários, que era um receptador de armas ilegais, que as baleias seriam, na verdade, submarinos os quais, nas estórias de boca em boca, foram convertidos em baleias etc. - mas Mussaleve insistia no devaneio de esperar pela chegada das baleias, até que, doente, acaba entrando no mar e desaparecendo. Assim, a pobreza e a falta de perspectivas em relação ao futuro levam, muitas vezes, personagens a perseguirem esperanças e apostarem em sonhos e devaneios, como esses de Bento, em sua ingenuidade infantil.

Deste modo, a obra de Mia Couto denuncia e problematiza diferentes mazelas no campo e na cidade, afetando principalmente os jovens pobres e os idosos. Se na cidade a modernidade e a ocidentalização podem trazer luxos, também ameaçam a tradição e os costumes moçambicanos, como em "Sangue de avó, manchando a alcatifa" (COUTO, 1993, p. 25-26); por outro lado, no interior mesmo que haja por vezes uma maior valorização das tradições, também não está imune à aculturação e muitas outras mazelas. E ainda que ameaçada pela ocidentalização e pela supervalorização da modernidade, a tradição persiste, como a mancha de sangue 
na sala, mesmo após a partida da avó com suas tradições e ancestralidades. Percebe-se que não apenas a tradição e os idosos são desrespeitados nessas narrativas, mas a infância aparece violentada, acometida por doenças, mazelas, minas, guerras, negligências de pais ou do Estado, fome, carências, desabrigo, morte, loucura... Enfim, a infância, principalmente, clama por proteção e amparo nessas histórias.

\section{O cotidiano da criança moçambicana e a ficção coutiana}

Nos artigos "A infância em Moçambique como lugar paratópico no discurso Adi Banana Lê" (CELESTINO; PASTORE; 2018), “A infância e o ser criança em uma comunidade moçambicana: dinâmicas de socialização, culturas e universos infantis a partir de uma vivência etnográfica" (PASTORE; BARROS; 2016) e no documentário Mwana, um olhar (ZANZAR, 2014), encontramos relatos recentes de hábitos, práticas culturais e experiências com a infância em uma comunidade humilde moçambicana e na capital Maputo, além de alguns registros do modo de vida de crianças pobres em Moçambique nos séculos $X X-X X I$, que podem servir de paralelo comparativo com a infância representada na obra literária coutiana.

Os artigos têm por objetivo descrever o cotidiano infantil dentro de uma comunidade moçambicana chamada Matola 
A, tocando em várias problemáticas também abordadas/ ficcionalizadas em narrativas de Mia Couto. Através do contato com as famílias do local, os pesquisadores ouviram relatos, críticas e aflições dos envolvidos; observaram atividades das crianças e de suas famílias em casa, na escola, no trabalho, na rua e junto da comunidade; registraram depoimentos, vivências e práticas culturais; analisaram valores, modos de pensar, tradições e modernidades, concluindo que, para uma compreensão mais ampla dos modos de existir da criança, é preciso relacioná-los ao seu contexto histórico e cultural.

Uma das questões relevantes citadas nos artigos diz respeito ao trabalho infantil, que em Moçambique (também no Brasil e em tantos outros países) é proibido, como já se viu, pela adesão a tratados internacionais sobre os direitos da criança. Isso significa que um cidadão moçambicano só pode começar a trabalhar a partir dos 18 anos, salvo em situações especiais. No entanto, na pesquisa realizada na comunidade de Matola $A$, os pesquisadores constataram que muitas crianças trabalham, desde muito jovens, ainda que ao serem questionadas sobre seus trabalhos, talvez cientes da lei que rege a infância, elas afirmam que não trabalham e que, na verdade, suas atividades são só afazeres, auxílios 
dentro do contexto familiar. Assim, o trabalho adquire uma nova nomenclatura/configuração: a de ajuda.

Por outro lado, nos artigos, Celestino e Pastore (2018), Pastore e Barros (2016), mostram como a ausência dessa participação infantil em atividades domésticas e econômicas poderia trazer maior dificuldade para a subsistência das famílias e poderia prejudicar até o desempenho educacional dos que conseguem frequentar a escola, por vezes, por incrível que pareça, visto que sem a renda conseguida com a "ajuda" das crianças, não haveria como comprar o material necessário para as aulas, como no exemplo do menino vendedor de bananas. Além disso, por conta do passado de guerras - que ainda gera temor-, os adultos consideram importante as crianças aprenderem a se cuidar e julgam que tais atividades constituem parte relevante da formação/educação das crianças para se tornarem sujeitos independentes, na premissa do cuidado mútuo. Por isso, tais valores e atitudes, concretizadas nas tarefas, são transmitidos de geração para geração e, apesar da responsabilidade dos pequenos com seus afazeres, muitos deles encontram tempo para brincar e ir à escola, ao menos nos relatos postos nos artigos, apesar de nas ficções de Mia Couto isso nem sempre acontecer. 
Essa intensa participação da criança nos afazeres domésticos e na captação de renda para a subsistência das famílias é abordada também em várias narrativas de Mia Couto, como as já mencionadas Terra Sonâmbula (COUTO, 2007), A menina sem palavras (COUTO, 2013a) e O beijo da palavrinha (COUTO, 2008, p. 1-29), em que crianças como o órfão Kindzu e "A menina de futuro torcido" não raro acabam responsáveis por sua própria subsistência/ sobrevivência ou pela de toda família em meio a guerras e outras adversidades, em prejuízo de seu desenvolvimento saudável, de sua formação escolar, de sua convivência familiar e de seu lazer infantil, substituídos por responsabilidades e atividades laborativas incompatíveis com sua etapa de amadurecimento. Aliás, isso acontece não apenas nessas comunidades moçambicanas ficcionais e fáticas, mas em tantas comunidades brasileiras e de outros países pobres, marcados pela violência, pela escassez e pela omissão do Estado, muitas vezes.

Outra peculiaridade moçambicana abordada nos artigos e muito presente nas narrativas de Mia Couto é a questão do pertencimento de uma criança à sua comunidade, ou seja, as crianças são vistas como responsabilidade comum daquele grupo, muitas vezes, responsabilidade de todos os membros 
da comunidade e não só da mãe ou de suas famílias. Por isso, desde muito pequenas, as crianças são livres para andar por onde quiserem, com isso passando a conhecer os demais moradores e a dominar a geografia, as histórias e a cultura local. As experiências vividas pelas crianças - tarefas, brincadeiras, contações, aulas etc. - fazem com que elas partilhem histórias, modos de ser e de pertencer àquela comunidade, fazendo com que, dessa forma, para o estudo da infância em determinada localidade, torne-se muito importante ouvir e observar as maneiras que elas têm de existir e atuar no mundo.

Essa independência, liberdade e autonomia infantil também são notadas em várias obras de Mia Couto, em que crianças (não raro levadas por circunstâncias difíceis) se veem forçadas a deambular e a se responsabilizar por seu próprio sustento e sobrevivência, como Kindzu e Muidinga da Terra Sonâmbula, este último menino que, na falta de outro adulto responsável, encontra no ancião Tuahir, cuidados, orientação e companhia. Mas, enquanto Muidinga está doente de amnésia, Kindzu revela profundo conhecimento, em suas memórias/diários, dos membros de sua comunidade, dos locais, dos costumes e das atividades desenvolvidas por cada um, desempenhando também várias atividades em sua comunidade desde bem pequeno. 
Por outro lado, nas obras de Mia Couto, encontramos também crianças isoladas, superprotegidas, sobretudo meninas, como "As três irmãs", "exclusivas e definitivas, postas e não expostas", em O fio das missangas (COUTO, 2004, p. 9-14), Gilda, Flornela e Evelina: "Filhas do viúvo Rosaldo que, desde que a mulher falecera, se isolara tanto e tão longe que as moças se esqueceram até do sotaque de outros pensamentos. O fruto se sabe maduro pela mão de quem o apanha. Pois, as irmãs nem deram conta do seu crescer: virgens, sem amores nem paixões" (COUTO, 2004, p. 9-14). Através dessa relação familiar, problematiza-se o machismo e a educação de meninas para a reclusão no lar e para as atividades domésticas, para a abnegação e o cuidado dos homens (pais, esposos...), crianças e lares, ao contrário da criação dada aos meninos, para a autonomia e a liberdade, resultando em meninas e mulheres em "silencioso e adiado ser", obrigadas a uma trajetória que não escolheram: "O destino que Rosaldo semeara nelas [...] cada uma feita para um socorro: saudade, frio e fome", ou seja, uma rimeira, uma receitista e a outra bordadeira (COUTO, 2004, p. 9-14). Em todo caso, também ocupadas, sem educação escolar formal, "ajudando" em tarefas domésticas e econômicas desde muito cedo, trabalhando sem parar trancadas em casa, como tantas crianças enfocadas em narrativas coutianas, nos 
artigos de Celestino e Pastore (2018, s.p.), Pastore e Barros (2016, s.p.) e como no documentário que a seguir cotejamos.

O documentário Mwana, um olhar, produzido pela Zanzar Filmes (2014) com apoio da UNICEF, Asdi, da Fundação pelo Desenvolvimento da Comunidade e contribuição da Action Aid, traz também um olhar sobre a infância, analisando as condições em que se encontram as crianças moçambicanas na capital Maputo. No curta metragem, temos depoimentos não só de profissionais da área de psicologia e antropologia, como também de representantes de organizações de proteção ao menor, apresentando os desafios que surgem ao longo da primeira idade. São relatos de inversão de papéis familiares, com filhos cuidando dos pais, e casos de diversos tipos de violência aos quais estão expostas as crianças nas mais diversas situações, como vemos ocorrer em tantas narrativas de Mia Couto. Além disso, parte do vídeo é formado por dois mini curtas, elaborados por adolescentes da Associação Horizonte Azul, que retratam dois polos da realidade infantil em Maputo: o das crianças de rua - que vivem em situação de vulnerabilidade - e das crianças da Escola Josina Machel, um espaço adequado ao desenvolvimento dos jovens e com muitas experiências exitosas, inclusive ligadas aos criadores do documentário. 
Exemplo de problematizações à situação de vulnerabilidade de crianças, muitas desabrigadas e em situação de rua encontramos em várias narrativas coutianas, como Terra Sonâmbula (COUTO, 2007), em que Muidinga, Kindzu e outras crianças vagam, sem acesso adequado à educação, saúde, abrigo, alimento, fugindo de guerras e de outras violências e adversidades. Além disso, vimos também o cerceamento do direito a uma infância plena e saudável em "A menina de futuro torcido" (COUTO, 2013a), na qual o pai depositava um desejo de viver às custas da filha, em uma visível inversão de valores e papéis, o que se desdobra também em graves formas de violência contra a criança, observadas em tantas comunidades pobres de diferentes locais.

Por outro lado, ainda que mais escassas as experiências exitosas com a infância nas narrativas coutianas - inclinadas à denúncia de mazelas para as quais nem sempre são vislumbradas saídas e soluções materiais - encontramos em 0 gato e o escuro (COUTO, 2001, s.p.), espaço para a valorização da diversidade e a possibilidade de uma convivência produtiva entre os diferentes, postos como os irmãos gatos, o claro e o escuro. Trata-se de comovente e criativa problematização (e denúncia) do racismo e da segregação racial, das mazelas, 
violências, traumas e crises (inclusive as de identidade) que podem causar a tantos sujeitos e povos. Por outro lado, a obra apresenta também a possibilidade tão palpável de se superar o racismo e a segregação, pelo amor ao próximo, pelo respeito ao diferente, pela valorização da diversidade, pela escolha da paz, pelo reconhecimento dos direitos do outro, pela superação do egoísmo...

Assim, a literatura contribui para uma releitura crítica do mundo, dialogando com o contexto histórico e, entre outras questões, problematizando vários aspectos da infância em Moçambique, na qual não se encontra apenas brincadeiras e "meninices", mas também várias responsabilidades que surgem de forma bastante precoce, como a participação em atividades laborais e domésticas da família, a aprendizagem sobre como cuidar de si, da família e até da comunidade tal qual observamos nos artigos citados e nas narrativas literárias do autor moçambicano. O desamparo à infância, por outro lado, surge como materialização de algumas mazelas, seja em relação à criança sem lar, deambulando sem a possibilidade de frequentar uma escola, fugindo de guerras e de outras formas de violência; seja em relação às crianças vítimas do machismo (como as meninas aprisionadas em "As três irmãs") também sem a possibilidade de frequentar a 
escola, de sair à rua, de socializar na comunidade... Enfim, a ficção e a realidade se encontram e se entrecruzam em muitos sentidos, inclusive no que tange à violência, à fome, ao abandono e ao desamparo que marcam muitas crianças reais (como as do documentário Mwana, um olhar, da Zanzar Filmes, 2014) e diversas personagens da narrativa coutiana.

\section{A criança entre a ficção coutiana e a História de Moçambique}

Através de exemplos como os citados até aqui, notamos como é possível estabelecer diálogos entre essas infâncias retratadas nos artigos e no documentário supracitados e muitas obras de Mia Couto que, como as demais literaturas africanas, problematizam a História. Aliás, muitas vezes, a narrativa literária propõe mesmo uma nova versão da narrativa histórica, permitindo uma releitura do passado e do presente histórico através do literário. Com isso, de acordo com o professor de literatura moçambicano Francisco Noa (2019, s.p.), a História que nas literaturas se insinua nos ajuda a orientar grande parte das nossas percepções do presente, no que toca, em particular, à verbalização do mundo, seja ela literária ou não literária.

Já para o professor da Universidade do Algarve, Petar Petrov (2014, p. 76), um tema de primordial importância nas literaturas que surgiram após as independências dos países 
africanos é o das identidades culturais dos povos, aspecto que se encontra particularmente presente na ficção de Mia Couto, que se empenha em construir uma identidade nacional junto ao povo moçambicano. Nessa perspectiva, suas narrativas, ainda que ficcionais, encontram-se permeadas pela História de seu povo, que passa a ser sua aliada como instrumento de denúncia das mazelas sofridas pela população local, inclusive, ou sobretudo, pelas crianças. Nesse sentido, suas obras literárias apresentam violências e tristezas, mas também resistência, resiliência e projetos de ser e de superação. O autor se vale em sua escrita do português "culto" e de elementos da cultura ocidental, as também de expressões de variadas línguas nacionais moçambicanas e de elementos das culturas nativas, além de criar neologismos e situações atípicas que tornam sua obra ainda mais expressiva. Somado a isso, ele retoma, em muitos de seus textos, elementos das religiosidades tradicionais animistas, sem esquecer de problematizar o cristianismo e sua influência sobre os povos e as culturas moçambicanas. Por tudo isso, sua inovadora literatura é dialógica e nas palavras de Petrov:

No processo de evolução da ficção narrativa em Moçambique, o projeto literário de Mia Couto apresenta-se particularmente inovador pelo facto de evidenciar mudanças significativas no 
modo de representação da realidade nacional. Poder-se-á afirmar que a sua atitude artística face aos temas sociais difere radicalmente da postura dos prosadores seus antecessores, antes da Independência, em 1975. (PETROV, 2014, p. 7)

Dentro desse projeto de representação da realidade nacional, em muitas narrativas de Mia Couto, jovens ocupam papeis centrais ou muito relevantes em diferentes contextos moçambicanos. Através da narrativa ficcional, aliando aspectos diversos da cultura e da História de Moçambique, somos conduzidos para além da questão identitária. Segundo o professor Petrov (2014, p. 82), os assuntos mais frequentes são de ordem existencial, como a solidão, o fatalismo, o obscurantismo, a desgraça, o sofrimento, a marginalização, o racismo, a segregação, o machismo, a identidade, entre outras. No entanto, temas ligados aos processos de colonização e descolonização, às guerras e problemas pós-coloniais, entre vários outros diálogos estabelecidos com episódios da História de Moçambique também são recorrentes nas narrativas literárias de Mia Couto.

As problemáticas do racismo, da segregação, do colonialismo, das guerras descolonizadoras e problemas pós-coloniais que afetam sobremaneira a infância das 
crianças moçambicanas, principalmente as negras, são abordadas em tantas narrativas já mencionadas até aqui e também em contos como "O embondeiro que sonhava pássaros" (COUTO, 2013b, p. 61-63), da obra Cada homem é uma raça, por exemplo. Neste texto, em terceira pessoa, aborda-se a chegada de um homem negro (que não tinha sequer o abrigo de um nome) ao bairro dos brancos, vendendo "lindos pássaros" cantores, ao som de sua gaita - tal como o flautista de Hamelin - encanta as crianças do local, que iam todas para a rua atrás dele: "O homem puxava de uma muska² e harmonicava ${ }^{3}$ sonâmbulas melodias. O mundo inteiro se fabulava." (COUTO, 2013b, p. 61).

Se por um lado, as crianças da obra se encantam, atraemse e se identificam com essa personalidade negra carismática, o que lembra a célebre afirmação de Nelson Mandela, de que ninguém nasce odiando o próximo por sua cor, origem ou religião. Por outro lado, os personagens adultos olham o talentoso negro com reservas e ensinam suspeitas aos seus filhos, ensinam a odiar o diferente, afirmando que aquele homem negro seria "sobremisso" e estaria a "invadir" o bairro do cimento. Ainda assim, ao surgir o "tio" - como os

\footnotetext{
2 Instrumento musical de sopro.

3 Tocava.

4 Que se coloca em posição superior.
} 
pequenos o chamavam - com seus pássaros e músicas, as "crianças emigravam de sua condição, desdobrando-se em outras felizes existências. E todos se familiavam ${ }^{5}$, parentes aparentes" (COUTO, 2013b, p. 63). Entre as crianças da obra, destaca-se Tiago que, apesar da desaprovação dos pais, insiste em seguir o passarinheiro e em admirá-lo, defendêlo, protegê-lo, discordando das suspeitas que the eram ensinadas pelos adultos e valorizando a diversidade.

Como a narrativa se passa durante o período colonial, em que a classe dominante é composta por portugueses brancos e seus descendentes, estes subjugam e exploram negros e, muitas vezes, não aceitam uma convivência isonômica e harmoniosa com aqueles que consideram inferiores e domináveis ou dominados. Por isso, mesmo o menino Tiago discordando dos rótulos e preconceitos dos mais velhos contra o negro e trabalhando por protegê-lo das represálias planejadas pelos adultos, como não consegue evitar o desaparecimento misterioso do passarinheiro. O vendedor negro, na narrativa literária, não oferece nenhum perigo às crianças nem aos adultos na obra, pelo contrário, traz felicidade aos pequenos, especialmente a Tiago, mas acaba vítima do preconceito, da discriminação e do segregacionismo.

5 Tornar-se família. 
Por outro lado, o menino que o admirava passa a ser o portador e o perpetuador de seus ensinamentos e de sua mensagem, mesmo depois de não o encontrar mais nem no embondeiro (morada do passarinheiro), para onde se dirige levando a gaita do desaparecido, encontrada nos arredores da prisão. Tiago passa a tocar ele próprio a gaita, descobrindo a origem dos misteriosos pássaros, mas não ouvindo a chegada dos homens nem o alastramento do fogo que os racistas ateiam à árvore onde o menino tocava a gaita do passarinheiro. Com isso, Tiago acaba duplicando o destino do passarinheiro, dentro do embondeiro que, para diversos povos africanos, é uma árvore sagrada/abrigo de espíritos e de sabedorias - que no conto abriga o segredo do vendedor e dos pássaros. Como galardão, no momento de sua morte, o menino se transfigura em raízes recém-descobertas, raízes moçambicanas, de forma que sua morte não se configura como um simples fim, mas como uma metamorfose (tão comum em narrativas coutianas) em uma outra forma de continuação da vida.

A aproximação do menino Tiago (filho de europeus) com o vendedor de pássaros (negro moçambicano, portador de mistérios legados à terra, à ancestralidade e à tradição moçambicana) se configura em um encontro/reunião entre/ 
de duas culturas para a formação de uma nova identidade cultural. Segundo Hall (2006, p.11), a partir do momento em que nos projetamos em determinada identidade cultural, como faz Tiago ao se identificar com o passarinheiro, internalizamos seus significados e valores, alinhamos nossos sentimentos subjetivos com os lugares que ocupamos no mundo social e cultural, de modo que "a identidade então costura [...] o sujeito à estrutura".

Retomando os ensinamentos de Mandela, em "O embondeiro que sonhava pássaros" (COUTO, 2013b, p. 61-63), o comportamento do menino Tiago mostra que aqueles que "aprendem a odiar, também podem ser ensinadas a amar, pois o amor chega mais naturalmente ao coração humano do que o seu oposto" (MANDELA, 2018, s.p.), como ocorreu com o menino, mesmo que esse amor e sua mensagem antirracista não o tenham salvado também da violência e da fúria racista. Então, urge a educação antirracista às nossas crianças, para se buscar mais isonomia entre as pessoas e os povos, para se combater o racismo estrutural que (se) perpetua (n)a desigualdade, (n)o preconceito, tão nocivos às relações sociais, como se nota em tantas obras coutianas e em "O embondeiro que sonhava pássaros" (COUTO, 2013b). 
Outro tema relevante, relacionado à infância e à educação na obra de Mia Couto, diz respeito à situação feminina na sociedade moçambicana colonial e pós-colonial, como já mencionamos através da narrativa curta "As três irmãs", de O fio das missangas, em que uma educação machista ensina às meninas (COUTO, 2004, p. 9-14) submissão e prendas domésticas, enquanto os meninos (ainda que também sofram violências) aprendem a dominar e a serem livres. A marginalização, a opressão e a violência a que estão sujeitas as mulheres e as meninas, desde as mais tenras idades, são objeto da atenção de Mia Couto (PETROV, 2014, p. 82) também no conto "Inundação", da obra O fio das missangas (COUTO, 2004, p. 25-28) - cujas histórias abordam delicadas questões que permeiam o universo de mulheres e crianças moçambicanas. A primeira leitura desse conto pode levar a crer que a família do narrador sofre pela perda do patriarca mas, em uma leitura mais atenta, percebemos que se trata também de abandono, que pode ser pior do que a perda pela morte pois, para a morte, não há outro caminho a não ser prosseguir em frente, sem o ausente. Mas o abandono é uma forma de violência que desvaloriza a figura abandonada (nesse caso, mulher e crianças) e, além de tristeza e da incompreensão, pode deixar também um sentimento de inferioridade, mágoas, alienação parental e até uma prolongada espera. 
Nesse conto, também a mulher é a que fica em casa com as crianças e desempenhando as atividades domésticas, enquanto o homem se sente livre para os abandonar e ir buscar/viver outras vidas. A felicidade antes representada pelas cartas de amor e pelas atividades domésticas bem desempenhadas, com o abandono e a tristeza começam a se desfazer os vestidos e as cartas de amor ofertadas pelo esposo no passado. Para representar a revolta, a saudade e a dor da mãe, o narrador-personagem também usa a imagem de um rio que passa a atravessar sua casa - recorrente em narrativas de Mia Couto para representar o tempo passando e a dinâmica da vida - todavia, ao invés de deixar as águas do rio correrem, a mãe as retém, provocando a inundação da casa, engolida pelas lembranças e pela saudade. Além disso, demonstram a solidão, a depressão, a sensação de fracasso, a autopunição e a desistência da mulher também o fato de a esposa passar a dormir no chão mantendo a cama vazia - "a cama é engolidora de saudade" (COUTO, 2004, p. 26) - negando-se a retomar sua vida e a esquecer o passado, ainda que o filho lhe peça para reagir.

Mais uma vez a criança, o filho, sofre dupla ou triplamente: pelo abandono do pai, a desolação da mãe e pela necessidade de ter que passar a cuidar da família e da casa, em mais uma 
inversão de papéis, como as já vistas em outras narrativas de Mia Couto. Um ponto culminante da aflição do menino é quando, numa noite, com um mau presságio, o filho vai ao quarto verificar se a mãe estava bem e se depara com ela delirando, pedindo silêncio para não acordar o pai/esposo, que ela teria atraído de volta com seu cantar, quando o homem continuava desaparecido/ausente. Causa mais medo e incompreensão ao filho notar, no dia seguinte, que as roupas e cartas estavam magicamente restauradas, entre outras lembranças assustadoras e doloridas de sua casa na infância, nada acolhedora nem segura.

Um outro assunto bastante recorrente na narrativa coutiana, que afeta sobremaneira as crianças, é a guerra e seu rastro de destruição, como se encontra em Terra Sonâmbula (COUTO, 2007), em O último voo do flamingo (COUTO, 2001) e em "O dia em que explodiu Mabata-Bata", do livro Vozes anoitecidas (COUTO, 1987), entre tantas outras obras coutianas. Em "O dia em que explodiu Mabata-Bata" (COUTO, 1987), por exemplo, o narrador em terceira pessoa relata um pouco da violência sofrida pelo povo moçambicano no período de guerra civil, após a descolonização, devido à disputa de poder entre a FRELIMO e a RENAMO. Mas, nessa pequena narrativa, encontramos uma grande concentração 
de críticas, ligadas tanto a temáticas existenciais quanto históricas, abordando a guerra, o problema das minas, o trabalho infantil, a orfandade, a solidão...

Para além das mazelas sofridas pelo povo, esse texto lança um olhar atento especialmente à infância, através da história do pequeno pastor Azarias, órfão desde muito cedo, abrigado por seu tio Raul e a avó Carolina, que teve sempre negada a sua condição de criança, proibido de brincar e de ir à escola, sofrendo maus tratos (violência intrafamiliar) e obrigado a trabalhar de sol a sol, cuidando do gado de seu tio, que constantemente ameaçava o menino, caso falhasse em suas tarefas. Com isso, o maior sonho dessa criança passa a ser frequentar a escola, como os filhos dos outros pais, mas se conformava com a negativa, reconhecendo-se como não sendo filho de ninguém.

O clímax da narrativa, adiantado pelo título da obra, quando o boi mais valioso que o menino pastoreava, chamado Mabata-Bata, pisa em uma mina e explode, apavora a criança, ciente das violências e represálias que sofreria em consequência do desaparecimento do animal. Incapaz de entender as causas da explosão, o menino busca explicações sobrenaturais para o evento, atribuindo o ocorrido a uma entidade chamada Ndlati, uma ave do 
relâmpago, explorando perspectivas religiosas nativas e animistas da natureza, tão recorrentes nas obras de Mia Couto e nas literaturas africanas de modo geral. O episódio, além de demonstrar a importância do conhecimento popular, dos costumes, das religiões ancestrais e da tradição na vida dessa criança, que não tem acesso ao saber científico e escolarizado, também problematiza a desproteção do menino, sem nenhum recurso para fazer valer seus direitos. Mas, o pior de tudo, é como a vida da criança termina menos valorizada que a do animal MabataBata, avaliados economicamente pelo tio, mais preocupado com os bois do que com o sobrinho fugido, a quem o tio é capaz inclusive de fazer falsas promessas de deixá-lo frequentar a escola a partir daquele dia, só para convencêlo a voltar ao trabalho, ainda mais preocupado com o prejuízo econômico.

Outra problemática abordada nesse conto que é recorrente na obra de Mia Couto é a mortalidade infantil. Aliás, a morte nem sempre surge como fator negativo, nem sempre determina um fim, mas muitas vezes se apresenta até como uma saída das misérias materiais ou como metamorfose para espaços maravilhosos/religiosos, habitados por ancestrais e elementos mágicos, tal qual uma mudança de estado, como 
vimos nos desfechos das histórias de Tiago, de Azarias, de Poeirinha, entre tantas outras.

Essa morte como metamorfose ou transmutação ocorre também no conto "Nas águas do tempo", do livro Estórias abensonhadas (COUTO, 2012, p. 9-14), a respeito da qual, em nota de abertura, Mia Couto relata sua visão sobre o momento histórico em que ela foi construída:

Onde restou o homem sobreviveu semente, sonho a engravidar o tempo. Esse sonho se ocultou no mais inacessível de nós, lá onde a violência não podia golpear, lá onde a barbárie não tinha acesso. Em todo este tempo, a terra guardou, inteiras, as suas vozes. Quando se Ihes impôs o silêncio elas mudaram de mundo. No escuro permaneceram lunares. Estas estórias falam desse território onde nos vamos refazendo e vamos molhando de esperança o rosto da chuva, água abensonhada. Desse território onde todo homem é igual, assim: fingindo que está, sonhando que vai, inventando que volta. (COUTO, 2004, p. 2)

A obra Estórias abensonhadas (COUTO, 2012) é uma coletânea de narrativas contadas após a guerra civil, em que Mia Couto trata, com delicadeza e sensibilidade, da importância da recuperação de Moçambique, desolada pela violência e pelas guerras, e da necessidade do resgate das raízes do povo moçambicano, do respeito à ancestralidade 
e da reconstrução de uma História da África pelas mãos do próprio povo africano, num resgate que a literatura poderia ajudar a proporcionar. É essa busca de reescrita africana, valorizando a ancestralidade e transformando a História da África, que encontramos em Nas águas do tempo (COUTO, 2012), por exemplo, em que o narrador-personagem relata os ensinamentos de seu avô, um idoso que navega com ele em um barquinho por um rio, que desemboca em um lago, temido pela mãe do menino. No caminho, o velho vai Ihe ensinando a colher a água do rio sempre na direção da corrente, nunca em direção oposta, para não contrariar os espíritos, a respeitar as religiões locais e a valorizar a tradição.

Nessa perspectiva, mais uma vez, o rio pode representar o tempo a escorrer, a vida a passar, enquanto o lago pode representar a eternidade (pós-morte) - prometida por várias religiões, entre elas algumas das africanas, para após o decurso do tempo existencial - onde só o avô é capaz de ver uns "panos brancos", que saúda sacudindo seu pano vermelho, enquanto ensina o neto a também respeitar e saudar os espíritos que sacodem os panos brancos, antes de voltarem para casa. E são esses mesmos gestos/ensinamentos que salvam os dois, quando caem na água do lago e começam a ser tragados para o fundo inexplicavelmente. 
Assim, os panos brancos sacudidos por entidades invisíveis à maioria podem representar as religiosidades ancestrais e tradições moçambicanas, que o avô lamenta não serem buscadas/vistas por mais ninguém e espera conseguir ensinar/legar ao neto, resgatando-as do esquecimento/morte. Aliás, esse intento parece alcançado quando, na última incursão com o avô, o menino o vê saltar do barco, abanando seu pano vermelho e o jovem, finalmente, também enxerga os panos brancos, motivo que o leva a tirar a camisa e agitá-la no ar em gesto de saudação aos espíritos que o estariam saudando, enquanto assiste ao pano vermelho de seu avô branqueando até desaparecer com todos os outros ancestrais. O retorno solitário para casa leva o narrador a entender, enfim, os ensinamentos de seu avô e a asseverar que um dia os ensinaria a seu filho, a fim de manter viva a memória de seus ancestrais, metaforicamente representados pelos panos balançados.

Com essas fortes ligações entre as crianças e os idosos, esse conto coutiano e tantos outros incentivam a redescoberta, pelo olhar infantil, das tradições transmitidas pelas gerações anteriores (avô, avós e outros idosos), as quais compõem uma identidade cultural moçambicana que valoriza os idosos, a tradição oral, a contação de histórias e as religiosidades nativas, reforçadas na obra de Mia Couto, 
mesmo em meio à crescente ocidentalização, muitas vezes criticada por narradores coutianos, ainda que reconhecida como irreversível. Nessa tarefa, a obra literária esgarça fronteiras entre ficção e História, problematizando esta e reescrevendo-a constantemente, a partir dos dramas de personagens humildes, como as várias crianças ficcionais mencionadas neste artigo. Além disso, através dessas infâncias tão verossímeis, narradas em "O dia em que explodiu Mabata-Bata", Terra Sonâmbula, "Inundação", "As três irmãs", "Nas águas do tempo", "O embondeiro que sonhava pássaros", $O$ beijo da palavrinha, O gato e 0 escuro, O menino no sapatinho, entre tantas outras, tecemse críticas às consequências funestas de guerras, minas, violências, racismos, segregação, exploração do trabalho infantil, abandonos, aculturações, cerceamento de direitos à educação, à saúde, à dignidade e tantas outras mazelas moçambicanas, brasileiras e de tantos outros países pobres, que continuam a assolar gerações e gerações.

\section{Referências}

ARIÈS, Philippe. História social da criança e da família. 2. ed. Rio de Janeiro: LTC, 1981.

CASTRO, Heloiza. Arte no Desenvolvimento Infantil: as 4 fases de Piaget. Blog Belas Artes. Joinville, 2019. Disponível em: https://belas. art.br/arte-no-desenvolvimento-infantil-as-4-fases-de-piaget. Acesso em: 4 jun. 2021. 
CELESTINO, Ricardo; PASTORE, Marina Di Napoli. A infância em Moçambique como lugar paratópico no discurso Adi Banana Lê. Caderno Seminal Digital, n. 29, v. 29, janeiro/junho de 2018. Disponível em: https://www.e-publicacoes.uerj.br/index.php/cadernoseminal/article/ view/30732/23604. Acesso em: 4 jun. 2021. COUTO, Mia. Vozes anoitecidas. 2. ed. Lisboa: Caminho, 1987. COUTO, Mia. Cronicando. Lisboa: Caminho, 1993. COUTO, Mia. O último voo do flamingo. 2. ed. Lisboa: Caminho, 2001a. COUTO, Mia. O gato e o escuro. 2. ed. Lisboa: Caminho, 2001b. COUTO, Mia. Na berma de nenhuma estrada. 4. ed. Lisboa: Caminho, 2002.

COUTO, Mia. Um rio chamado tempo, uma casa chamada terra. São Paulo: Cia das Letras, 2003.

COUTO, Mia. O fio das missangas. Lisboa: Caminho, 2004.

COUTO, Mia. Terra Sonâmbula. São Paulo: Cia das Letras, 2007.

COUTO, Mia. O beijo da palavrinha. Lisboa: Caminho, 2008.

COUTO, Mia. E se Obama fosse africano? Ensaios. São Paulo: Cia das Letras, 2011.

COUTO, Mia. Estórias abensonhadas. São Paulo: Companhia das Letras, 2012.COUTO, Mia. A menina sem palavras. São Paulo, 2013a.

COUTO, Mia. Cada homem é uma raça: contos. São Paulo. Cia das Letras, 2013 b.

COUTO, Mia. O menino no sapatinho. Lisboa: Caminho, 2013c.

FOUCAULT, Michel. Vigiar e punir. Petrópolis: Vozes, 1995.

HALL, Stuart. A identidade cultural na pós-modernidade. 11. ed. Rio de Janeiro: DP\&A, 2006.

MANDELA, Nelson. Nelson Mandela, um dos maiores líderes da história. Exame. 18 de julho de 2018. Disponível em: https://exame.com/mundo/10frases-marcantes-de-nelson-mandela-um-dos-maiores-lideres-dahistoria/. Acesso em: 8 jun. 2021. 
NOA, Francisco. Império, mito e miopia: Moçambique como invenção literária. São Paulo: Kapulana, [E-book]. 2019.

PETROV, Petar. O projecto literário de Mia Couto. Lisboa: Centro de Literaturas e Culturas Lusófonas e Europeias, Faculdade de Letras da Universidade de Lisboa, 2014.

HILLESHEIM, Betina; GUARESCHI, Neuza Maria de Fátima. De que infância nos fala a psicologia do desenvolvimento? Psicanálise e Política. Psicologia da Educação, v. 25, 2007. Disponível em: https://psibr.com. br/leituras/desenvolvimento-e-educacao/de-que-infancia-nos-falaa-psicologia-do-desenvolvimento-algumas-reflexoes\#: :text=A\%20 inf\%C3\%A2ncia\%20passa\%20a\%20ser,si\%20e\%20sobre\%20o\%20mundo. Acesso em: 3 jun. 2021.

MARQUES, Moama Lorena de Lacerda. Velhice e infância nas estórias de Mia Couto: um diálogo de afeto e cumplicidade. Anais do ENLIJE: Ed. Realize, 2012. Disponível em: https://editorarealize.com.br/editora/ anais/enlije/2012/c2b8c95ae77ec823d6fc777bdfa541bf 667346 .pdf. Acesso em: 5 jun. 2021.

PASTORE, Marina Di Napoli; BARROS, Denise Dias. A infância e o ser criança em uma comunidade moçambicana: dinâmicas de socialização, culturas e universos infantis a partir de uma vivência etnográfica. Revista África(s), v. 3, n. 6, p. 20-35, julho/dezembro de 2016.

UNICEF. Convenção sobre os Direitos da Criança: Instrumento de direitos humanos mais aceito na história universal. Brasil, CDC 30 anos: 2019. Disponível em: https://www.unicef.org/brazil/ convencao-sobre-os-direitos-da-crianca\#: :text=Entrou $\% 20 \mathrm{em} \% 20$ vigor\%20em\%202,Unidos\%20n\%C3\%A30\%20ratificaram\%20a\%20 Conven\%C3\%A7\%C3\%A3o. Acesso em: 2 jun. 2020.

ZANZAR. Mwana, um olhar. Moçambique, Maputo: Zanzar Filmes, 2014.

\section{Eloísa Porto Corrêa Allevato Braem}

Doutora em Letras Vernáculas (Literatura Portuguesa) pela UFRJ, possui pós-doutorado em Literatura Comparada pela UERJ. 
Professora adjunta da UERJ, no Campus FFP, onde leciona nos Mestrados PPLIN e PROFLETRAS.

É coordenadora do GP UERJ/CNPq Literaturas, Artes Visuais e Formação de Professores, com interesse nas áreas de Literaturas em língua portuguesa, Literaturas infantojuvenis, ilustração, violência e insólito.

E-mail eloisaporto@gmail.com

Lattes: https://lattes.cnpq.br/2275093398092913

ORCID iD: http://orcid.org/0000-0001-5356-3059

\section{Lina Paula Jasbick Tonack Beckmann}

Mestra em Letras pelo Universidade do Estado do Rio de Janeiro (Área de concentração: Linguagens e Letramentos), possui Especialização em Literatura Infanto-Juvenil pela Universidade Federal Fluminense.

E-mail: linabeckmann@gmail.com

Lattes: $\underline{\text { https://lattes.cnpq.br/4180873356741179 }}$ 